DOI: https://doi.org/10.47264/idea.lassij/4.1.20

Vol. 4, No. 1, (January-June 2020): 231-241

Research Article

URL: https://www.ideapublishers.org/index.php/lassij

\title{
Jirga and Dispensation of Social Welfare Services: A Case Study of Mohmand Tribal District, Pakistan
}

\author{
Fakhre Alam ${ }^{1}$, Shakeel Ahmad ${ }^{1} \&$ Abida Bano*2 \\ 1. Department of Social Work, University of Peshawar, Peshawar, Pakistan. \\ 2. Institute of Peace \& Conflict Studies, University of Peshawar, Peshawar, Pakistan.
}

Received: March 16, 2020

Published Online: December 08, 2020

\begin{abstract}
This paper examines Jirga's role in providing social welfare to marginalized (poor and orphans) and persons with disabilities in Tribal Districts of Pakistan. In Pakistan's tribal districts, due to lack of written laws and deficiencies in formal social welfare structure, Jirga has also got a contour of informal welfare institutions for rendering services to society's downtrodden poor, orphans, and persons with disabilities. This research uses a case study approach and engages qualitative methods for data collection and data analysis. A total of 23 qualitative in-depth individual interviews and focused group discussions are used, while data is analysed thematically. The study investigates "whether Jirga provides social protection to the poor, orphans, and persons with disabilities in selected case study." The findings reveal that due to absence of efficient and responsive formal social welfare system, vulnerable segments of tribal districts mostly depend on Jirga's indigenous welfare practices for their social protection. Jirga is cost-effective, sympathetic, inclusive, and cares for the needs of vulnerable segments in the selected case. However, Jirga's benevolent role and its efficiency have been somewhat affected by colonial legacies, militancy, etc. The welfare being provided to poor, orphans, and persons with disabilities by Jirga has also been significantly reduced.
\end{abstract}

Keywords: Jirga, Informal Social Welfare, Social Protection, Marginalised Community, Persons with Disabilities, Vulnerable Segments.

\section{Introduction}

Societies at times have their mechanisms for the delivery of social welfare and social protection services alongside the government. However, the informal ways to provide social protection are informed by the cultures, thus vary across the countries. Every society has its mechanisms of ensuring justice to its people (Steensma \& Vermunt, 2013:4). Such mechanisms range from formal to informal - from the court system to elders' council at the community level. The formal mechanisms of justice are based on well-defined laws, while informal mechanisms are based on society's precedents and norms (Shinwari \& Siddique, 2015). Historically, in tribal societies, social trust lies with the centuries-old social institutions (informal) for their longevity and egalitarian structure instead of the flawed and hierarchical formal mechanisms to disseminate social justice. Thus, the societies with the weaker and less effective formal justice system depend on informal justice mechanisms (Ghazi, 2017:77). However, they vary across the cultures, religions, norms, and customs of the societies (Naz et al., 2012). For instance, East Africa has Gacaca ${ }^{l}$ practice; the Middle East has the practice of Sulha ${ }^{2}$; New Zealand has the 
practice of Maori Tribe ${ }^{3}$ (Gohar, 1996).

There are also specific indigenous mechanisms like Jirga ${ }^{4}$, Panchayat, and Fasilo to protect marginalized segments of Pakistan. In the tribal districts in the North West of Pakistan, there had been two parallel systems of justice in practice; one was governed by Frontier Crimes Regulations (FCR) while the other was administered through traditional code - Pakhtunwali ${ }^{5}$. In the first case, judicial and executive powers had been concentrated in the hands of district administration (previously political administration), who exercised them contrary to the accepted norms and human rights (Dil, 2016). On the other hand, the formal justice system is also greatly influenced by Pakhtunwali. It is important to note that Pakhtunwali is a combination of several conduct codes like Jirga, Melmastia ${ }^{6}, \mathrm{Hujra}^{7}, \mathrm{Badal}^{8}$, Tor and Peghoor, ${ }^{9}$ Tarboorwali, ${ }^{10}$ and Nanawati, ${ }^{11}$ among others (Zadran, 1967).

Since the study assesses the issue in the context of tribal district Mohmand in the Khyber Pakhtunkhwa, it is important to highlight the Pashtun society's vital features in Mohamand tribal district for clarity of contextual understanding. The social structure of society in Mohmand District comprises eight main tribes Dawizai, Baizai, Halimzai, Khwaizai, Babazai, Tarakzai, Safi, and Utman Khel (Arif, 2015). These tribes are further divided into several clans or Qam/Qaum ${ }^{12}$. Each Qam has a specific territorial and geographical area. The Qam is further divided into sub-sections, also known as Khels ${ }^{13}$. A Khel or extended family is called $a$ Koranay or Khandan ${ }^{14}$. Traditionally, Mohmand people prefer to live in an extended family system where parents and their married sons and children live together under the same roof if compatibility permits. Being a tribal society like other Pakhtun areas, the people usually resort to Jirga to acquire their rights or seek justice. There are three types of Jirga systems prevailing in the Mohmand district: Olasi Jirga ${ }^{15}$, Koranay or Shakhsi Jirga ${ }^{16}$, and FCR or Sarkari ${ }^{17}$ Jirga $^{2}$ (Mahmood et. al, 2018).

In the tribal districts, including Mohmand, the Jirga system is confined to conflict and dispute resolution and has different roles and functions. For example, it is a local and tribal decisionmaking body that deals with social, economic, and political issues. It has also adopted a developmental aspect in tribal districts of Pakistan. Different scholars have well explored all these roles of Jirga. For instance, from conflict and dispute resolution perspectives, different researchers have enriched Jirga's literature (Wardak, 2002, 2004; Islam, 2013). In the other context, Jirga has been linked and signified with the peacebuilding process (Yousufzai \& Gohar, 2005). Some scholars have richly contributed to exploring the dynamics, process, and legitimacy (Shinwari, 2011, 2012, and 2015). In most studies, Jirga has been explored from the perspective and lenses of culture (Barth, 1953). Moreover, the political and economic dimensions of Jirga have been explored by different scholars (Zadran, 1977).

Nevertheless, in all these studies, Jirga's legal, political, historical, and cultural aspects have been explored. The social welfare aspect of Jirga remained ignored and understudied in the literature on Jirga and Pashtuns (Wasai et al., 2020). As in Pashtun society, especially in the tribal district Mohmand, the Jirga also adjudicates the rights of poor, orphans, and persons with disabilities. Thus, the Jirga system can be termed as a type of informal social welfare institution, especially for the poor, orphans, and PWDs. In tribal districts, including Mohmand, the rights of vulnerable groups like other segments of society are mostly at the disposal of Jirga where the right to property, liberty, business, inheritance, and others are all dealt with by Jirga (Community Appraisal \& Motivation Programme, 2013). Jirga members - Jirgaeez $^{18}$ are 
selected from those male members of the community who are relatively older, experienced, and command respect for their integrity. Another reason for the local membership is being aware of the situation and having the appropriate skills to resolve community disputes and inter communal conflicts. Moreover, they are selected from broader and diverse society sections, including religious scholars and community elders.

The Jirga members play a crucial role in the tribal setup, as do the formal courts' judges. Therefore, they are considered providers in the dispensation of social protection to the marginalized people and are culturally accepted authority for decision making. Jirgaeez constitutes a vital component of the Jirga system as the adjudicators and decision-makers in the study area (Yousufzai \& Gohar, 2005). On the one hand, a sizable section of the marginalized community strives to protect their rights due to a lack of formal and efficient social welfare entities, and the Jirga system faces many challenges to deal with these issues, on the other. This situation sometimes results in the reluctance of vulnerable segments in consulting Jirga for fear of injustice or bias in the dispensation of justice (Shinwari \& Siddiqui, 2015). However, the marginalized segments of district Mohmand are mostly dependent on the indigenous welfare practices of Jirga. As far as the role of credible Jirgaeez is concerned, in the current insurgency in the study area, those Jirgaeez who enjoyed the trust of the local communities are either killed or migrated to other peaceful, settled areas. As per the estimate, among Jirgaeez (3616) total strength in the former FATA, more than 630 have been killed in violent conflicts (Hilali, 2010:24). This situation created a leadership vacuum at the local level, resulting in diminishing Jirga's role (Afridi, 2012).

\section{Materials and Methods}

The study adopts a qualitative approach to answer the research questions concerning Jirga's role in transacting and dispensing social welfare practices among the vulnerable sections of society in the tribal district Mohmand. Scholars argue that the qualitative methodology is critical and useful when the researcher needs to obtain information about a specific group's context, behaviours, values, and opinions (Mack et al., 2011:1). Since Jirga is an indigenous social institution that provides various services in the study area; thus, qualitative methodology is the most appropriate to study this peculiar institution's workings. The study engages the snowballing sampling technique and enlists a sample of 32 male respondents from the selected case. Due to Pashtun society's cultural sensitivities and segregated nature, the researcher could not access the womenfolk in the selected area. Thus, the study is limited on that account. The smaller sample size in the study is justified through the study conducted by Mason (2010) with the title "sample size and saturation in $\mathrm{PhD}$ studies" using qualitative interviews and found that most common sample sizes were 0-20 and 0-30 (followed by 0-40, 0-10 and 0-25).

The research uses in-depth individual interviews, focused group discussions, and observation as data collection tools with target respondents. The researchers have conducted twenty-three in-depth interviews, and one focused group discussion with the research respondents. Nine out of 23 individual interviews are conducted with Jirgaeez ${ }^{19}$ (three individual interviews with Sarkari, Olasi, and Koranay Jirga each), and two were with Islamic scholars. Furthermore, 12 in-depth interviews were also conducted with vulnerable groups (four each with poor, orphans, and persons with disabilities). The vulnerable segments were identified with the help of a pilot survey. In the very first stage of the pilot survey, the poor, orphans, and persons with disabilities were identified for the proposed topic. Afterward, the data were refined as per the proposed 
research methods and sample size. For the present study, poverty is determined as having no or minimal access to resources like money, political administration, clan size, lack of support from clan members compared to the opponents. The orphans were limited to only those whose parents (one or both) had died. Also, persons with disabilities were limited to the physically challenged and visually impaired exclusively. The remaining categories of research respondents like Jirgaeez and religious scholars were selected through purposive sampling. The details of the respondents have been given.

\section{Anomalies and Deficiencies in the Social Welfare Strategies}

The governmental social welfare agencies are not well established in the tribal districts yet. The Social Welfare Department in the tribal districts is under the district administration domain and responsible for providing different special services like white cane, wheelchair, scholarships, and monetary packages to the poor, orphans, and persons with disabilities. However, their performance is under question (Mahmood et al., 2020). According to one of the respondents - a Jirga member stated,

"We have a social welfare department and population welfare department in FATA Secretariat, but in actual, they play no role in providing social welfare services due to multiple reasons such as limited resources, clan politics, and favouritism."

Furthermore, the child protection department has also not played its due role in providing rights and protection to the children in need. Due to sheer injustice in the provision of wheelchairs, white cans, scholarships meant for the vulnerable groups have not been provided to the deserving people. Instead, they are distributed among the influential and well-approached people of the tribes and clans. On the contrary, Jirga plays a crucial role in providing these services to the target communities, which entails access to the political agent (now district commissioner), which is a difficult task for the community's marginalized people.

As far as the selection criteria of vulnerable segments to dispense the social protection services are concerned, Jirgaeez plays a crucial role in its selection, providing a list of the vulnerable groups to the district administration. Henceforth, the exiting status of deserving groups is not very encouraging. One of the respondents (an official of the FATA Social Welfare Department) noted that there are 11000 registered Persons with Disabilities in all the Tribal districts without having any specialized education centres or services. However, according to a reasonable estimate, the number of persons with disabilities would be higher but not registered due to lack of information. Unlike the settled districts of KP, most people of the Tribal districts do not know about the procedure of registration and its outcomes and benefits. One of the Jirga members' services to those who are uneducated but deserving is to help them register and access specialized services at the tribe or clan level. Sometimes, the district administration provides special incentives in the form of money or other services to the vulnerable groups with Jirga members' help and consultation. Persons with Disabilities have low or no access to socioeconomic resources; thus, they remain dependent on their families.

The wealthy and resourceful people of the society also extend their support to uphold the deprived sections informally and provide for their basic needs. However, these efforts are disorganized and happen through personal contacts and information. Hence, the scope of such 
charities remains limited and restricted to specific localities. Jirga could also play a significant role in channelling these funds to underprivileged sections more comprehensively. Jirga members are connected to almost all community members and better know the people needing social welfare and social protection across the district. Also, the community's wealthy people could trace the poor, orphans, and PWDs through Jirga and make their support more systematic and sustainable than random help.

The social welfare department, the population welfare department, and the district administration have been making efforts to minimize the miseries of the low-income people and other needy persons. However, they have not been able to play their designated role; neither have they managed to provide proper support promptly in emergencies. During an interview, one of the Jirgaeez noted that the authorities should focus on the vulnerable people's problems to end their miseries. He suggested that setting up educational institutions or vocational centres will help them stand on their own feet and become self-sufficient. In Pakistan's settled areas, welfare organizations and relatively well-established institutions are there to help the people in need of social protection. Funds are allocated to them for their financial and legal support, or charities are being collected to achieve the purpose.

On the contrary, vulnerable segments, the poor of tribal districts, live in a hostile environment with minimal access to resources. Some governmental programs, such as the Benazir Income Support Program (BISP) and Pakistan Baitul Mal, have benefited society's downtrodden to some extent. Additionally, non-government organizations (NGOs) have also extended their support in helping the needy in cash and kind both. They provide cash, health, and education facilities to the weaker sections to lessen their miseries. However, it is not a durable solution and provides timely relief only.

Furthermore, the NGO sector works through the influential persons in the community that bars them from reaching out to people at the grassroots level. Thus, they should improve their policy and practice by directing their activities toward poor people than spending money on the upper strata of the tribe. There are fewer educational institutions for orphans, providing free education to orphans and supported by Pakistan Baitul-Mal and different NGOs. The rights of orphans in the Jirga system have a close relation with widow rights.

\section{The Dilemma of Jirga Justice: Compassion and Compulsion}

Like other parts of the country, Khyber Pakhtunkhwa has got at least three parallel systems of justice that are in practice. These systems are categorized into formal and informal mechanisms such as courts, Disputes Resolution Councils (DRCs) in urban centres, and the rural context of the Jirga system (Azim et al., 2018). As far as the current legal structure of tribal districts is concerned, it is mostly based on an informal justice system. Jurisdiction of Pakistan's judicial system and courts have not yet been extended to tribal districts in its real sense (Khattak, 2018). Hence, implementing a complete formal judicial system will take some time. Most of the Jirga members stated that formal district and session courts and patwari system (land record department) are yet to be established to decide the general public or vulnerable groups like the poor, orphans, and persons with disabilities. Due to legal hurdles and barriers in tribal districts, the people in general resort to Jirga for both civil and criminal disputes. Jirga practices Pakhtunwali that is an unwritten code to decide communal disputes as per society's norms. Jirga thrives on social legitimacy and functions through mutual social trust. Shinwari and Siddique (2015) argue that FCR Jirga is administered by the district administration and 
influential people of the tribes. Olasi and Sakshi Jirgas are administered through local community elders Mashraan (community elders), and its decisions are usually based on the codes of Pakhtunwali.

Scholars also posit that people's resorting to Jirga and Pakhtunwali is not only emotional but practical. One of the reasons is the cumbersome access to the formal justice system and availing the services for ordinary people like the poor, orphans, and PWDs. Besides, a multitude of reasons like the trust deficit on state institutions and complexities of formal systems, lack of financial resources for hiring lawyers, long duration of the legal process have kept the practice of Jirga alive (Shinwari \& Siddique, 2015). Conversely, the informal justice system is relatively easier to access as the Masharan (Jirgaeez) mostly live within the communities, making it convenient to reach out to.

Despite many issues in the Jirga system, the tribesmen also have sympathy with the Poor, Orphan, PWDs, and other vulnerable segments of their community. Vulnerable groups may feel more sympathy and preference in their favour compared to the formal justice system. Jirga system, in general, prefers a soft corner for vulnerable segments in its decisions as per the codes of Pakhtunwali, though with changing trend, sympathy has been reduced a lot from Jirga System due to various internal and external factors. The rich culture and traditional customs are getting weaker. The current Jirga system does not promote such sympathy as was practiced before the current restive time (Khan et al., 2019; Khan et al., 2020).

Some of the respondents also noted specific weaknesses of the Jirga system and said that it has gone expensive with the time. However, it was completely free of charge in the past. Secondly, since the Jirga members are from within the community, there are chances of influence on the decision by the influential segments, making the weaker segments vulnerable. Additionally, there is no codified or fundamental set of laws according to which the Jirga will decide; instead, the decisions are based on the limited sources of information of Jirga members and less evidence-based.

Furthermore, Jirga membership is exclusively male by gender, thus can be called gender-biased with almost no representation of women segment. One of the Jirga members stated that there had not been any participation of women in Jirga historically. Thus, no women participate in the proceedings, neither as participant nor complainant. Instead, male members of their families play their proxy should they have any issue under process in Jirga. Nevertheless, women can be included in the justice process by introducing other types of mechanisms such as Dispute Resolution Councils, which work in the settled districts of Khyber Pakhtunkhwa.

\section{Jirga's Role in Social Protection of Orphans and Widow Rights}

The vulnerable segments, such as the poor and PWDs, can directly approach Jirga members about any claim or reservation regarding their rights. However, there is no such strategy in place through which an orphan can directly claim their due rights like Poor and PWDs at Jirga's platform. As per most respondents, orphans are one of the most excluded groups from the Jirga decision process. Due to such exclusion and limited participation in the Jirga system, the orphans face injustices like women have. There are many reasons for the exclusion of orphans from the Jirga system. One of their young age is not considered reliable to give suggestions and claim their rights to Jirgaeez. Hence, it is challenging for orphans to claim their due rights to Jirga justifiably and reasonably. One of the respondents from the orphans' category stated: 
"In a Koranay Jirga, my family elders (Jirgaeez) made me sign a document of inheritance distribution when I was only eight years old. At that time, I did not know about the Jirga's decision. Approximately after twelve years, I discovered that the decision of the Jirga was merely a formality. My rights had been denied, and justice had not been done."

Although the mother of an orphan (widow) can be considered as a source of adjudication in due course of rights in the Jirga system, however, no women participate in Jirga proceedings under the prevailing traditions and customs in society. Thus, in Koranay Jirga, orphans and widows cannot claim their due rights due to honour, prestige, and family pressure. They are generally denied their inheritance rights, and Jirga facilitates the process. In other words, Jirga upholds society's norms rather than dispensing social justice to the deserving ones. Widow rights are closely related to the rights of orphans in the Jirga justice system. Widows are not included in land and other property rights due to society's patriarchal nature in the tribal districts. Thus Jirga does not go against the norms of Pakhtunwali. In some instances, Jirga facilitates the acquisition of women and orphans' rights in the form of cash or other material things but not in the land's shape.

Furthermore, orphans do not include in the Jirga system due to the discrimination in the process of Waak (mandate). Waak from orphans is not practical like other cases in Jirga. Their immediate family plays a significant role in providing them the due rights. When the family supports the orphan, then the matter is resolved in no time. Usually, Korany Jirga adjudicates the cases of inheritance rights or those cases which occurred within the family. However, in Korany Jirga, when the orphan family is unwilling to grant their due rights, the case goes to Olasi Jirga. On the contrary, it is complicated for the orphan to protect their due rights because of dominant power dynamics Olasi Jirga. In Koranay Jirga, there are more chances of sympathy with orphans as compared to Olasi Jirga. One of the respondents said,

"Our family had 25 shops in the main town of Mian Mandi in Mohmand District. When my father was killed, our family elders (uncles) decided in an internal Jirga that the entire rent of the joint family's shops would be paid to the orphans for 25 years."

Conversely, in the case of Olasi Jirga, no such sympathy but a standard procedure is upholding the norms. Considering the discussed situations in Olasi Jirgas, the Jirgaeez also tend towards influential segments of society as per the respondents. The opponent parties usually have a robust socio-economic background compared to orphans. The influential and Jirgaeez take care of each other and influence Jirga's decision at any stage of its proceeding. Nevertheless, Jirgaeez is credible, and justice is delivered in Jirga according to most of the respondents.

It is important to note that Jirga's modes' multiplicity has affected its effectiveness to an extent. For example, Sarkari Jirga had affected traditional Jirga's contour and the confidence of the vulnerable segments of the tribal society. So, Sarkari Jirga's role of welfare and sympathy with the vulnerable has significantly been curtailed with the inclusion of power and favouritism. The traditional and Koranay Jirga are considered very handy in delivering justice to society's vulnerable segments in the tribal districts. Among many other reasons, one can be the code of Pashtunwali, which reflects the rights of poor, orphan, and PWDs and converge new avenues for the social protections of the oppressed groups. In Pakhtunwali, the concept of charity has 
been embedded since time immemorial. The poor and vulnerable segments have been provided social protection by the Jirga through Pakhtunwali in the tribal district Mohamad of Pakistan.

\section{Conclusions}

The study's findings show fewer and efficient formal entities available for dispensing social welfare and social protection to vulnerable segments in traditional societies. Therefore, some informal ways to provide care and protection to the needy are also in practice. In Pashtun society, these vulnerable segments strongly rely on indigenous social protection methods, including family and community support. The formal mechanisms are not only meager, inaccessible, but also expensive and beyond affordability. For instance, there can be multiple hurdles to acquiring rights and protection in the case of the poor, including an expensive judicial system, hiring a lawyer, hard to understand formal judicial procedures, among others. Besides, there is no such concept of sympathy or equity in the formal justice system for orphans and persons with disabilities but a standard procedure. On the contrary, sympathy and compassion are the basis of informal ways to provide social protection to the identified categories of people in the selected case.

It is a fundamental requirement of every human being to have a smooth and peaceful life and co-existence. From time to time, societies have been developing different social protection mechanisms for regulating their lives in different parts of the world. Mostly in developed societies, the formal systems based on well-defined laws and regulations perform the duty but on the other hand the backward societies still rely on the informal systems, which commensurate with their own customs, norms, and culture, and religion. The present study focused on Jirga's role in dispensing social protection to the needy and vulnerable segments in Mohmand's tribal district. In a narrow view, Jirga has been restricted to resolving disputes and conflicts; however, Jirga is a more powerful institution with a broader potential to provide welfare and rendering rights to the poor, orphans, and PWDs. In the current situation, Jirga plays a significant role in the welfare of the mentioned vulnerable groups because there is no proper extension of the formal judicial system and formal social welfare structure to serve the general masses' welfare. Jirga informally serves these groups in their decisions by applying equity. One of the reasons that Jirga is termed as contradictory to the fundamental human rights principles is its resolving issues through an equity approach. However, most community backs up Jirga for its egalitarianism and equity approach, which is why it survived the test of time and is still functional.

It is also an established reality that tiny heed has been paid to developing social welfare entities in the tribal districts of Khyber Pakhtunkhwa. The people of ex-FATA have been promised in the recent merger and reform program that formal social welfare strategies and judicial system, i.e., the jurisdiction of Supreme Court and High Courts, would be extended to tribal districts that would be more effective than the existing one. Similarly, other social welfare entities will also be established and strengthened. However, establishing formal mechanisms of social welfare is not only slow but also face multifold hurdles. It seems that the institutional changes in the tribal districts will take some time to install and take roots. Thus, the people of tribal districts must rely upon Jirga to resolve their legal issues and rights till the institutions mentioned above get streamlined. Similarly, if these institutions are strengthened enough and gain their grounds, the poor, orphans, and PWDs will mostly be dependent on informal justice system (Jirga) to seek their due rights because they cannot afford the cost complexities of the 
formal judiciary. Moreover, Jirga is cost-effective, sympathetic, inclusive, and protective of the rights of the poor, orphans, and persons with disabilities.

\section{References}

Afridi, G. S. (2012). FATA Leadership in Decline, Daily Dawn. https://www.dawn.com/news/706928.

Arif. (2015). One Person Can Change the World. ARY News. https://blogs.arynews.tv/oneperson-can-change-the-world/.

Azim, S. W., Mehmood, W., \& Hussain, S. (2018). Swat Conflict in Retrospect: Violence and Jarga among the Swat Pakhtuns in Pakistan. Liberal Arts and Social Sciences International Journal (LASSIJ), 2(1), 37-48. https://www.ideapublishers.org/index.php/lassij/article/view/43

Barth, F. (1953). Political Leadership Among Swat Pathans. Athlone.

Community Appraisal \& Motivation Program. (2013). Reforming the Jirga System: Sensitization on Fundamental Human Rights, Islamabad, Pakistan. http://www.camp.org.pk/wp-content/uploads/2016/03/Jirga-manual-final-Eng.pdf

Dil, U. (2016). Black Law (FCR) in Federally Administered Tribal Areas (FATA) of Pakistan. Atlas Crops. http://www.atlascorps.org/blog/black-law-in-federally-administeredtribal-areas-fata-of-Pakistan/

Ghazi, H. (2017). Helping Afghanistan's Informal Dispute Resolution Systems Follow Afghan Law in Criminal Matters: What Afghanistan Can Learn from Native American Peace making Program, Michigan State International Law Review, 25(1), 77-118. https://digitalcommons.law.msu.edu/ilr/vol25/iss 1/3

Gohar, A. (1996). Indigenous Institutions for Decision Making in Pakistan. Restorative Justice. http://restorativejustice.org/rj-library/indigenous-institutions-for-decision-makingin-pakistan/7647/\#sthash.9KN5wKAP.dpbs.

Hilali, A. Z. (2010). FATA: The Strategic Depth of Pakistan. Margalla Papers, 3(1), 18-50. https://ndu.edu.pk/issra/issra_pub/articles/margalla-paper/Margalla-Papers-2010/02FATA-The-Strat-Depth-of-Pakistan.pdf

Islam, F. U., Faqir, K., \& Atta, M. A. (2013). Jirga: As Conflict Resolution Tool in Pakhtoon Society. Gomal University Journal of Research, 29(1), 87-95. http://www.gomal.pk/GUJR/PDF/June-2013/87-95.Jarga.pdf

Khan, S., Wazir, T., \& Khan, A. (2019). The Effects of Militancy and Military Operations on Pashtun Culture and Religion in FATA. Liberal Arts and Social Sciences $\begin{array}{llll}\text { International Journal } & \text { (LASSIJ), } & 3(1), & \end{array}$ https://www.ideapublishers.org/index.php/lassij/article/view/98

Khan, Z., Ullah, R., \& Kamal, U. (2020). Pathways of Youth Radicalisation in Pashtun Society: Applying the Anomie and Strain Theory. Liberal Arts and Social Sciences International Journal (LASSIJ), $3(2), \quad 150-157$. https://doi.org/10.47264/idea.lassij/3.2.17

Khattak, A. R. K (2018). Missing the Point. Daily Dawn. https://www.dawn.com/news/1382845.

Mack, N., Woodsong, C., Macqueen, KM, Guest, G., and Namey, E. (2011). Qualitative Research Methods: A Data Collector's Field Guide. North Carolina, Family Health International. https://www.worldcat.org/title/qualitative-research-methods-a-datacollectors-field-guide/oclc/212880122 
Mahmood, A., Ullah, S., \& Ashfaq, S. (2018). The Evolution of Jirga System: A Conflict Resolution Mechanism in FATA. Liberal Arts \& Social Sciences International Journal (LASSIJ), 2(1), 21-28. https://www.ideapublishers.org/index.php/lassij/article/view/41

Mahmood, A., Ullah, F., \& Shah, S. F. H. (2020). Problems of Orphan Children in State Sponsored Orphanages of Khyber Pakhtunkhwa, Pakistan. Liberal Arts \& Social Sciences International Journal (LASSIJ), 4(1), 102-113. https://doi.org/10.47264/lassij.4.1.10

Mason, M.(2010). Sample Size and Saturation in PhD Studies Using Qualitative Interviews. Forum: Qualitative Social Research, 11(3), Art. 8. http://www.qualitativeresearch.net/index.php/fqs/article/download/1428/3028.

Naz, A., Khan, W., Rehman, H., Daraz, U., Hussain, M. (2012). The Relational Analyses of Pakhtun Social Organization (Pakhtunwali) and Women's Islamic Rights Relegation in Malakand division, KP Pakistan. International Journal of Sociology and Anthropology, 4(3), 63-67. https://doi.org/10.5897/IJSA11.025

Shinwari, N. A. (2012). Understanding FATA: Attitudes Towards Governance, Religion, and Society in Pakistan's Federally Administered Tribal Areas. Community Appraisal \& Motivation Programme (CAMP), Vol. V.

Shinwari, N. A. (2011). Understanding Jirga: Legality and Legitimacy in Pakistan's Federally Administered Tribal Areas. Community Appraisal and Motivation Program (CAMP). http://crossasiarepository.ub.uniheidelberg.de/3124/1/Understanding-Jirga-072011.pdf.

Shinwari, N. A., Siddique. (2015). Understanding the Informal Justice System: Opportunities and Possibilities for Legal Pluralism in Pakistan. Community Appraisal \& Motivation Programme (CAMP). 16-17.

Steensma, H., Vermunt, R. (2013). Social Justice in Human Relations: Societal and Psychological Consequences of Justice and Injustice ( $1^{\text {st }}$ ed.), Vol. No. 2. Plenum Press.

Wardak, A. (2002) Jirga: Power and Traditional Conflict Resolution in Afghanistan, In John Strawson (ed.) Law After Ground Zero. Cavendish.

Wardak, A. (2004). Jirga: A Traditional Mechanism of Conflict Resolution in Afghanistan, UK: $\quad$ University of Glamorgan. http://unpan1.un.org/intradoc/groups/public/document s/apcity/unpan017434.pdf.

Wasai, Ullah, J., \& Bano, A. (2020). Militancy and Pashtun Culture: Challenges and Developments in Pashtun Society in Khyber Pakhtunkhwa, Pakistan. Liberal Arts \& Social Sciences International Journal (LASSIJ), 3(2), 115-127. https://doi.org/10.47264/idea.lassij/3.2.14

Yousufzai, H. M., Gohar, A. (2005). Towards Understanding Pukhtoon Jirga: An Indigenous Way of Peacebuilding and More, Peshawar: Just Peace International. https://justpeaceint.cjb.net

Zadran, A. (1977). Socio-Economic and Legal-Political process in a Pashtun Village, South Eastern Afghanistan, Ph.D. Thesis, Department of Anthropology, State University of New York, Buffalo.

\section{Notes:}

1 A traditional mechanism of justice in which local community members participate to decide their matters

2 Sulha arose to respond to the need to restore order between families, tribes, or villages so that quarrels and feuds do not threaten the stability of the larger community 
${ }^{3}$ Indigenous system of Maori people in New Zealand, practicing their own traditional values in form of tribes to settle disputes and provide justice.

${ }^{4}$ Council of elders, composed of exclusively male membership, chosen from the community to decide the communal issues in Pashtun society.

5 Pakhunwali is an unwritten ethical code that Pashtuns practice to settle their disputes. Jirga interprets and applies various tenets of Pakhtunwali to resolve diverse issues among the community members. In this article, Pakhtunwali is only once italicized for being non-English word.

${ }^{6}$ Hospitality, or the honourable use of wealth

7 Men's guest house, a place of male activities

${ }^{8}$ Mostly translated as revenge but it also means exchange of any goodness at the time of need

9 Stigma and sarcasm

${ }^{10}$ Kinship, lineage system or power blocks within a Khel competing for power and prestige

${ }^{11}$ Arrangements for an apology by a wrong doer through mediators

${ }^{12}$ A social unit within tribe also called sub-tribes

${ }^{13}$ A collection of a few extended families within sub-tribes

${ }^{14}$ A Khandan or Koranay is extended family in sub-tribe

${ }^{15}$ A traditional mechanism of justice between or intra Tribes in erstwhile FATA

${ }^{16}$ A traditional mechanism of justice within village or individuals prevailing in erstwhile FATA

${ }^{17}$ Appointed by the Government.

${ }^{18}$ The chief or elder of a village, tribe, or community in ex-FATA. The term is italicized only once for emphasis.

${ }^{19}$ Members of Jirga are called Jirgaeez in local language. 